\title{
Determination of $\mathrm{Na}, \mathrm{K}, \mathrm{Mg}$ and $\mathrm{Ca}$ in Biodiesel by LS F AAS and HR-CS F AAS: Studies that Supported the Proposal of the ABNT NBR 15556 Norm
}

\author{
Ligia C. C. de Oliveira, ${ }^{a}$ Mariana A. Vieira, ${ }^{* b}$ Anderson S. Ribeiro, ${ }^{b}$ Paula M. Baptista, ${ }^{a}$ \\ Rodrigo A. Gonçalves ${ }^{a}$ and Reinaldo C. de Campos $^{\sharp, a}$ \\ ${ }^{a}$ Departamento de Química, Pontifícia Universidade Católica do Rio de Janeiro (PUC-Rio), \\ Rio de Janeiro-RJ, Brazil \\ ${ }^{b}$ Laboratório de Metrologia Química, Centro de Ciências Químicas, Farmacêuticas e de Alimentos, \\ Programa de Pós-Graduação em Química, Universidade Federal de Pelotas (UFPel), \\ 96160-000 Capão do Leão-RS, Brazil
}

\begin{abstract}
Recentemente, a Associação Brasileira de Normas Técnicas (ABNT) lançou uma série de normas, relacionadas com a determinação de $\mathrm{Na}, \mathrm{K}, \mathrm{Mg}$ e $\mathrm{Ca}$ em biodiesel, recomendando procedimentos similares àqueles das normas europeias e americanas, mas também introduzindo uma norma alternativa (ABNT NBR 15556), que possibilita a determinação dos 4 elementos usando a técnica de espectrometria de absorção atômica com chama (FAAS). Neste trabalho, apresentam-se os estudos de otimização e validação que dão suporte a essa norma, bem como a comparação do desempenho de um equipamento com fonte de linhas com outro de fonte contínua. Entre os fatores otimizados, os baixos valores de taxa de aspiração e o uso de uma solução de óleo mineral em xileno para o ajuste da viscosidade entre soluções das amostras e de calibração devem ser destacados. Testes de precisão (repetitividade e precisão intermediária) mostraram valores adequados, comprovando a robustez do método, e os limites de detecção estiveram confortavelmente abaixo daqueles propugnados pelas legislações brasileira e internacional. A exatidão foi confirmada por testes de recuperação e pela participação em exercícios interlaboratoriais de proficiência promovidos pela Agência Nacional de Petróleo, Gás Natural e Biocombustíveis (ANP). A determinação dos 4 elementos por F AAS traz evidentes vantagens econômicas ao produtor, uma vez que se trata de um equipamento mais barato na sua aquisição e manutenção.
\end{abstract}

Recently, ABNT (Brazilian Association of Technical Standards) has presented a set of norms related to the determination of $\mathrm{Na}, \mathrm{K}, \mathrm{Mg}$ and $\mathrm{Ca}$ in biodiesel, recommending procedures similar to those of the European and American norms. However, it has also introduced an alternative norm (ABNT NBR 15556) wherein these 4 elements can be determined by flame atomic absorption spectrometry (F AAS). This work presents the studies that have supported this proposal and compares the performance of linear source equipment with a continuous source one in the application of the norm. Among the optimized factors, the low aspiration rate and the use of mineral oil solution in xylene to adjust the viscosity between samples and calibration solutions are highlighted. Precision tests (repeatability and intermediary precision) have shown adequate values, confirming the robustness of the method. Limits of detection were suitably below the legislation limits. The accuracy was confirmed by recovery tests as well as by the participation in interlaboratory proficiency tests promoted by the National Agency on Oil, Natural Gas and Biofuels (ANP, Brazil). The determination of these 4 elements by F AAS brings evident economic advantages to the producer, once F AAS is less expensive to purchase and maintenance.

Keywords: biodiesel, ABNT NBR 15556 norm, metals, flame atomic absorption spectrometry

*e-mail: maryanavieira@ hotmail.com

\#In memoriam

Dedicatory: This work is dedicated to Professor Reinaldo Calixto de Campos who passed away on February 7th, 2012. The same day Reinaldo and some authors discussed the last details to finish this work. We would like to thank Reinaldo for his contribution to the development of the Analytical Chemistry in Brazil. 


\section{Introduction}

Nowadays biodiesel represents a real alternative to diesel for internal combustion engines. The use of biodiesel has the potential to lower the environmental impact of automobile transport due to the net reduction of the amount of emitted gaseous $\mathrm{CO}_{2}$ to the atmosphere, contributing to the decrease of greenhouse gas emissions. Biodiesel is obtained by transesterification of vegetable oils (soybean, sunflower, palm, etc.) and animal fats using an excess of a primary alcohol (most commonly methanol) in the presence of a homogeneous or heterogeneous catalyst. The main reaction products are biodiesel and glycerol. Used vegetable oils are also considered a low cost source for obtaining biodiesel, permitting waste recycling. Feedstock composition may influence the properties of produced biodiesel,,$^{1-4}$ and besides the traditional feedstock materials (vegetable oils or animal fat), the production of biodiesel using microalgae has been recently studied and appears to possess high production potential. ${ }^{5}$

For its adequate use, biodiesel must obey strict regulations and the determination of $\mathrm{Na}, \mathrm{K}, \mathrm{Mg}$ and $\mathrm{Ca}$ is part of biodiesel characterization of pure biodiesel (B100) or blends with petroleum diesel (B2, B5 and B10). In the production process, $\mathrm{Na}$ and $\mathrm{K}$ come from the alkali catalysts $(\mathrm{NaOH}$ and $\mathrm{KOH})$ used in the transesterification reaction, while $\mathrm{Mg}$ and $\mathrm{Ca}$ come from the washing process. These elements should be removed during the biodiesel production process, but they can appear as contaminants in the final product. If present in the final product, $\mathrm{Na}$, $\mathrm{K}, \mathrm{Mg}$ and $\mathrm{Ca}$ may form insoluble soaps, leading to the formation of deposits in the filters also contributing to the corrosion of motor parts. ${ }^{6}$ Thus, the determination of these elements is necessary because their presence above certain levels may change the characteristics of the product use. The current specification for biodiesel imposed by ANP, the Brazilian Agency for Oil, Natural Gas and Biofuel, ${ }^{7}$ in consonance with the European and American regulations ${ }^{8}$ by means of standard methods such as EN 14108, ${ }^{9}$ EN $14109,{ }^{10}$ EN $14538^{11}$ and ASTM D6751 ${ }^{12}$ establishes a limit of $5 \mathrm{mg} \mathrm{kg}^{-1}$ as the maximum allowed concentration for $\mathrm{Na}$ plus $\mathrm{K}$ or $\mathrm{Ca}$ plus $\mathrm{Mg}$.

In the literature, several articles have been published reporting methods for the determination of $\mathrm{Na}, \mathrm{K}, \mathrm{Mg}$ and $\mathrm{Ca}$ in biodiesel. Santos et al. ${ }^{13}$ reported a simple method for the simultaneous determination of $\mathrm{Na}, \mathrm{K}, \mathrm{Mg}, \mathrm{Ca}$ and $\mathrm{P}$ in biodiesel samples by inductively coupled plasma optical emission spectrometry (ICP OES), after a sample dilution with ethanol. The obtained limits of detection (LOD) were $0.1,0.3,0.005$ and $0.03 \mu \mathrm{g} \mathrm{g}^{-1}$ for $\mathrm{Na}, \mathrm{K}, \mathrm{Mg}$ and $\mathrm{Ca}$, respectively, in the original sample. Chaves et al. ${ }^{14}$ developed a method for the determination of $\mathrm{Na}$ and $\mathrm{K}$ in biodiesel by flame optical emission spectrometry (F OES). Samples were prepared as microemulsions with propan-1-ol and aqueous acid solution. For calibration, inorganic aqueous calibration solutions were used. The use of microemulsion was also proposed by Jesus et al. ${ }^{15}$ for the determination of $\mathrm{Na}$ and $\mathrm{K}$ in biodiesel by flame atomic absorption spectrometry (FAAS). The microemulsion was constituted of $n$-pentanol, Triton X-100 and water, and calibration was performed with aqueous calibration solutions. The LODs were 0.1 and $0.06 \mu \mathrm{g} \mathrm{g}^{-1}$ for $\mathrm{Na}$ and $\mathrm{K}$, respectively. De Oliveira et al. ${ }^{16}$ developed a method for the determination of Na by F OES using dry decomposition for sample preparation. The LOD and LOQ (limit of quantification) in the original samples were 1.3 and $4.3 \mathrm{mg} \mathrm{kg}^{-1}$, respectively.

Since $\mathrm{Na}, \mathrm{K}, \mathrm{Mg}$ and $\mathrm{Ca}$ determinations in biodiesel are of regulatory importance, European and American normalization entities advocate the use of recommended analytical procedures for these determinations. For the determination of $\mathrm{Na}$ and $\mathrm{K}$, the European norms, EN $14108^{9}$ and EN $14109,{ }^{10}$ respectively, propose sample dilution with xylene followed by F AAS determination. For the determination of $\mathrm{Mg}$ and $\mathrm{Ca}$, a similar sample pre-treatment was used and ICP OES instrumental determinations were recommended (EN 14538); ${ }^{11}$ ASTM suggests similar procedures (ASTM D6751). ${ }^{12}$ In all these cases, the calibration is performed with organic-metallic standard solutions, diluted in xylene, and care must be taken in the viscosity matching between the calibration and sample solutions. More recently, ABNT (Associação Brasileira de Normas Técnicas - Brazilian Association of Technical Standards) has launched a set of norms related to the determination of $\mathrm{Na}, \mathrm{K}, \mathrm{Mg}$ and $\mathrm{Ca}$ in biodiesel. ABNT advocates sample dilution with xylene and instrumental determination by F AAS for $\mathrm{Na}(\mathrm{NBR} 15554)^{17}$ and K (NBR 15555) ${ }^{18}$ and ICP OES for $\mathrm{Mg}$ and $\mathrm{Ca}$ (NBR 15553), ${ }^{19}$ following the same trend of the European and American norms. However, ABNT NBR $15556^{20}$ norm has also introduced the determinations of $\mathrm{Na}, \mathrm{K}, \mathrm{Mg}$ and $\mathrm{Ca}$ by F AAS in contrast to European and American norms that recommend the use of F AAS technique only for $\mathrm{Na}$ and $\mathrm{K}$.

The recent introduction of continuous source high resolution spectrometers for atomic absorption measurements indicates the possibility of improvements in the analysis performance. High-resolution continuum source atomic absorption spectrometry (HR-CS AAS) has a number of advantages over the line source approach (LS AAS) in the determination of trace elements in complex matrices due to its improved background 
correction capabilities, the visibility of the spectral environment around the analytical line, the increased primary source intensity, the neighboring pixel baseline compensation process and the possibility of sequential multielementar determination. ${ }^{21}$ Thus, LOD, analytical throughput and accuracy are improved in relation to the conventional LS AAS. Recently, Quadros et al. ${ }^{22}$ developed a simple method for the determination of $\mathrm{Al}$, $\mathrm{Cu}, \mathrm{Fe}$ and $\mathrm{Mn}$ in biodiesel by HR-CS ET AAS, showing precise and accurate results.

The aim of this work was to present studies that have supported the proposal of the ABNT NBR $15556^{20}$ norm, a Brazilian norm for determination of $\mathrm{Na}, \mathrm{K}, \mathrm{Mg}$ and $\mathrm{Ca}$ in biodiesel. Also, we aimed to compare the performance of LS F AAS and HR-CS AAS in the application of this norm, proving that it is possible to perform the analysis using only atomic absorption methods.

\section{Experimental}

\section{Instrumentation}

The measurements were carried out in two AAS spectrometers: a conventional line source model 1100B atomic absorption spectrometer (Perkin Elmer, Bodenseewerk, Germany) with a flame atomizer and a continuous (deuterium lamp) background correction system. Sodium, K, Ca and Mg hollow cathode lamps (Varian, Mulgrave, Australia) were used as line sources. The continuous source atomic absorption spectrometer was a model ContrAA 300 (Analytik Jena, Jena, Germany) with a flame atomizer, a xenon short-arc lamp operated in hot spot mode (as the primary continuum radiation source), an Echelle double monochromator and a CCD (charge coupled device) line detector. In the HR-CS AAS, a simultaneous evaluation of 200 pixels, which corresponds to a spectral environment of about $\pm 0.2 \mathrm{~nm}$ around the central pixel, was used. The instrumental parameters of both apparatus are displayed in Table S1 and their optimization is discussed in the next section. Samples were weighed using a microbalance model Adventurer AR 2140 (Ohaus, Pine Brook, NJ, USA) with a precision of $\pm 0.0001 \mathrm{~g}$.

\section{Materials, reagents, solutions and samples}

All reagents were of analytical reagent grade. Xylene P.A. and mineral oil (viscosity ranging from 10.8 to $13.6 \mathrm{~mm}^{2} \mathrm{~s}^{-1}$ and specific mass of $0.856 \mathrm{~g} \mathrm{~mL}^{-1}$, both from Vetec, Rio de Janeiro, Brazil) were used. Individual $\mathrm{Na}, \mathrm{K}$, $\mathrm{Mg}$ and $\mathrm{Ca} 1000 \mathrm{\mu g} \mathrm{g}^{-1}$ standard solution (Spex, Metuchen, NJ, USA) as well as a multielemental organometallic
$885 \mu \mathrm{g} \mathrm{g}^{-1}$ standard solution (S21+k, Conostan, Champlain, NY, USA) were used to prepare the calibration solutions. The diluent solution (mineral oil in xylene, $120.0 \mathrm{~g} \mathrm{~L}^{-1}$ ) was prepared by diluting $120.0 \mathrm{~g}$ of mineral oil to $1000 \mathrm{~mL}$ with xylene in a volumetric flask. This solution was used as a diluent for the calibration solutions and as blank. Biodiesel samples from different origins (castor, soybean, canola, cotton, babassu, sunflower, etc.) were investigated. These samples were provided by biodiesel plants located in different regions of Brazil and also by the Laboratory of Biofuels from Pontifical Catholic University of Rio de Janeiro (PUC-Rio).

\section{Procedure}

Samples were prepared in accordance with the procedure described by ABNT NBR 15556 norm: $1.0 \mathrm{~g}$ of biodiesel was accurately weighed in a $15.0 \mathrm{~mL}$ polypropylene flask, diluted to $10.0 \mathrm{~mL}$ with xylene, and homogenized. Calibration solutions were prepared from appropriate dilution of the standard solutions with the mineral oil in xylene solution (120.0 $\left.\mathrm{g} \mathrm{L}^{-1}\right)$ for matching their viscosity with those of the sample solutions. Sample solutions were then analyzed by F AAS according to the instrumental parameters shown in Table S1.

\section{Parameter optimization}

Observation height (measured by the burner height), flame composition (measured by the acetylene flow rate) and aspiration rate were optimized using a complete $\left(3^{3}\right)$ factorial planning and levels are showed in Table S2. Data were analyzed using Statistica 7.0 Statsoft software and the obtained results are presented in Tables S3 and S4.

The choice of the range for height burner was based on the knowledge that the absorbance reaches a maximum near the center of the flame and decreases when the oxidation of the element begins to occur. To the choice of gas flow rate, it was considered the limitations of the equipment and the proportions established by the manufacturer. It is important to note that xylene is a fuel and to work with an oxidizing flame, the flow rate must be small. This does not occur when aqueous solutions are aspirated since the contribution of the stoichiometry of the flame is quite small. The sensitivity measured by the slope of the calibration curves taken in each of the studied conditions was used as response. Calibration curves were prepared according to the ABNT NBR 15556 norm, with calibration solutions of $0.10,0.20,0.30$ and $0.40 \mathrm{mg} \mathrm{L}^{-1}$. At first, the line source equipment was used. 


\section{Results and Discussion}

Viscosity adjustment of the calibration solutions using mineral oil

Special attention must be given to the question of the viscosity matching between samples and calibration solutions, considering that biodiesel of different sources present different viscosities. The choice of the mineral oil solution is important to promote the adjustment of viscosity and is a procedure recommended by the norm for the analysis of biodiesel. Since the dilution factor of the samples was previously defined $(10.0 \% \mathrm{~m} / \mathrm{v})$ and in order to minimize the viscosity differences between biodiesel samples and calibration solutions, mineral oil was added to the calibration solutions to promote this adjustment. The viscosity of mineral oil in xylene solutions with different concentrations was measured and obtained results are shown in Figure S1. The viscosities of the sample solutions of biodiesel of different sources were also measured and showed values ranging from 0.82 to $0.86 \mathrm{~mm}^{2} \mathrm{~s}^{-1}$ (babassu, cotton, palm, soybean, sunflower and castor), although those derived from castor and canola (dry) oils presented viscosities of 0.90 and $0.94 \mathrm{~mm}^{2} \mathrm{~s}^{-1}$, respectively. According to Figure $\mathrm{S} 1$, the mineral oil solution in the xylene solution corresponds to a concentration of $120 \mathrm{~g} \mathrm{~L}^{-1}$, which was then used as diluent and final medium for the calibration solutions.

\section{Parameter optimization}

Pareto charts for the 4 analytes are displayed in Figure S2. For Na, the significant effects were the aspiration rate (linear), observation height (linear) and acetylene flow (linear). For K, besides these three effects, the interaction between aspiration rate (linear) and acetylene flow rate (linear) was also significant. For $\mathrm{Mg}$, the significant effects were the aspiration rate (linear), observation height (linear) as well as the interaction between the observation height (linear) and the acetylene flow rate (linear). For Ca, only the aspiration rate (linear) and the acetylene flow rate (linear) were significant.

Figure S3 shows some of the response surfaces for the studied elements. In the case of $\mathrm{K}, \mathrm{Mg}$ and $\mathrm{Ca}$, it is possible to observe that the critical point was out of the studied range. However, due to practical limitations, it was not logical to perform further experiments in the direction of the indicated maximum sensitivity. For instance, the surface response for $\mathrm{K}$ indicates that the maximum response must be expected at larger aspiration rates. However, aspiration rates above 1.5 could lead to a lean flame (an organic solvent is being aspirated) and a correspondent increased noise. Similar considerations should be made to $\mathrm{Mg}$ and $\mathrm{K}$ as well. Thus, Table $\mathrm{S} 1$ displays optimum values taking into account these practical aspects. A similar optimization was performed with the continuous source equipment, and the optimized parameters are also displayed in Table S1.

\section{Studies of sample stability}

Since biodiesel of different sources present different compositions (and consequently, different properties, such as viscosity and density), the matrix influence was investigated by observing the slopes of analyte addition curves with biodiesel samples of different feedstock. Calibration curves in the $120.0 \mathrm{~g} \mathrm{~L}^{-1}$ mineral oil in xylene solution were also investigated. Analyte addition calibration curves were prepared by spiking biodiesel samples with appropriate microvolumes of the organometallic standard solutions and diluting $(10.0 \% \mathrm{~m} / \mathrm{v})$ with xylene. External calibration curves were prepared as described in the procedure section. Results (Tables 1 and 2) show that no significant multiplicative matrix effects were observed (F AAS and HR-CS F AAS) in relation to the external calibration curve prepared in $120.0 \mathrm{~g} \mathrm{~L}^{-1}$ mineral oil in xylene solution $(t$ test, $\mathrm{p}<0.05)$. Thus, external calibration

Table 1. Slopes ( \pm standard deviation, SD) of external calibration and analyte addition curves on biodiesel samples of different sources by LS F AAS using the procedure recommended by the ABNT NBR 15556 norm

\begin{tabular}{lcccc}
\hline Biodiesel & \multicolumn{3}{c}{ Slope \pm SD / $\left(\mathrm{L} \mathrm{mg}^{-1}\right)$} \\
\cline { 2 - 5 } & $\mathrm{Na}$ & $\mathrm{K}$ & $\mathrm{Mg}$ & $0.156 \pm 0.004$ \\
\hline Castor & $1.299 \pm 0.100$ & $0.525 \pm 0.008$ & $1.570 \pm 0.049$ & $0.135 \pm 0.000$ \\
Soybean & $1.160 \pm 0.114$ & $0.499 \pm 0.007$ & $1.546 \pm 0.023$ & $0.141 \pm 0.004$ \\
Canola & $1.372 \pm 0.103$ & $0.551 \pm 0.000$ & $1.530 \pm 0.069$ & $0.136 \pm 0.008$ \\
Cotton & $1.262 \pm 0.116$ & $0.538 \pm 0.004$ & $1.620 \pm 0.052$ & $0.149 \pm 0.003$ \\
Babassu $^{\text {External }}{ }^{\mathrm{a}}$ & $1.206 \pm 0.024$ & $0.564 \pm 0.014$ & $1.547 \pm 0.030$ & $0.147 \pm 0.005$ \\
\hline
\end{tabular}

${ }^{\mathrm{a}}$ In $120.0 \mathrm{~g} \mathrm{~L}^{-1}$ mineral oil in xylene. 
Table 2. Slopes ( \pm standard deviation, SD) of analyte addition curves on biodiesel samples of different sources by HR-CS F AAS using the procedure recommended by the ABNT NBR 15556 norm

\begin{tabular}{lcccc}
\hline \multirow{2}{*}{ Biodiesel } & \multicolumn{3}{c}{ Slope $\pm \mathrm{SD} /\left(\mathrm{L} \mathrm{mg}^{-1}\right)$} \\
\cline { 2 - 5 } & $\mathrm{Na}$ & $\mathrm{K}$ & $\mathrm{Mg}$ & $0.190 \pm 0.009$ \\
\hline Castor & $1.637 \pm 0.052$ & $0.488 \pm 0.020$ & $2.564 \pm 0.079$ & $0.186 \pm 0.005$ \\
Soybean & $1.572 \pm 0.036$ & $0.500 \pm 0.007$ & $2.525 \pm 0.091$ & $0.191 \pm 0.013$ \\
Canola & $1.631 \pm 0.088$ & $0.507 \pm 0.008$ & $2.530 \pm 0.059$ & $0.181 \pm 0.009$ \\
Cotton & $1.684 \pm 0.138$ & $0.485 \pm 0.025$ & $2.393 \pm 0.054$ & $0.191 \pm 0.001$ \\
Babassu & $1.594 \pm 0.071$ & $0.526 \pm 0.019$ & $2.637 \pm 0.094$ & $0.191 \pm 0.008$ \\
\hline External $^{\mathrm{a}}$ & $1.631 \pm 0.088$ & $0.490 \pm 0.023$ & $2.492 \pm 0.054$ & \\
\hline
\end{tabular}

${ }^{\mathrm{a}}$ In $120.0 \mathrm{~g} \mathrm{~L}^{-1}$ mineral oil in xylene.

using this calibration curve could be performed. Note that the added concentrations were quite below the limits permitted to biodiesel by the legislation. This happened due to the fact that most of the samples received in the laboratory are below the upper value of the used concentration range.

\section{Calibration and sample solution stability}

Reyes et $a l .{ }^{23}$ have indicated that metal solutions in organic medium are unstable solutions, and analytical signal tends to decrease with time. Calibration and sample solutions prepared as described in the Procedure section were proved to be unstable, dropping down to $18 \%$ of their original concentration value after $2.5 \mathrm{~h}$ standing in glass or plastic flasks. Similar results were found by Jesus et al. ${ }^{15}$ who proposed the stabilization of these solutions by microemulsion formation. Thus, due to this lack of stability, it is important to analyze the calibration and sample solutions immediately after their preparation, making the use of the whole automatic sampler carrousel difficult. In relation to the stability of the original sample, no information was found in the literature, considering the determination of these metals in biodiesel. Thus, the following experiment was made: biodiesel samples were prepared in the laboratory by the transesterification of a soybean vegetable oil with methanol, using $\mathrm{NaOH}$ and $\mathrm{KOH}$ as catalysts. According to the usual procedure, ${ }^{24}$ the obtained products should be washed 3 times. However, only one washing procedure was performed in order to obtain a product with high $\mathrm{Na}$ or K contents. Just after its preparation, the biodiesel sample obtained was analyzed each $24 \mathrm{~h}$, using freshly prepared calibration solutions. According to results presented in Table 3, the Na content decreased along the measurements, while $\mathrm{K}$ concentration kept reasonably constant. This behavior must be taken into account for an accurate analysis. It was tried to perform a similar study for $\mathrm{Mg}$ and $\mathrm{Ca}$. However, no sample with sufficient content of these elements was available in the laboratory at the time of this experiment and we did not succeed in producing samples with the necessary concentrations of $\mathrm{Mg}$ and $\mathrm{Ca}$ by using contaminated washing water.

Table 3. Slopes ( \pm standard deviation, SD) of external calibration by LS F AAS using the procedure recommended by ABNT NBR 15556 norm and $\mathrm{Na}$ and $\mathrm{K}$ response stability in biodiesel samples prepared with $\mathrm{NaOH}$ and $\mathrm{KOH}$ as catalysts, respectively

\begin{tabular}{lccc}
\hline time / h & $\begin{array}{c}\text { Slope } \pm \mathrm{SD} / \\
\left(\mathrm{L} \mathrm{mg}^{-1}\right)\end{array}$ & $\mathrm{R}$ & $\begin{array}{c}\text { Concentration } \pm \mathrm{SD} / \\
\left(\mathrm{mg} \mathrm{L}^{-1}\right)\end{array}$ \\
\cline { 2 - 4 } & & $\mathrm{Na}$ & \\
\hline 0 & $1.754 \pm 0.047$ & 0.9997 & $1.248 \pm 0.010$ \\
24 & $2.151 \pm 0.053$ & 0.9998 & $1.350 \pm 0.004$ \\
48 & $2.065 \pm 0.041$ & 0.9998 & $1.277 \pm 0.006$ \\
72 & $2.088 \pm 0.059$ & 0.9997 & $1.097 \pm 0.004$ \\
96 & $2.115 \pm 0.048$ & 0.9998 & $0.932 \pm 0.010$ \\
\hline & & $\mathrm{K}$ & \\
\hline 0 & $0.728 \pm 0.012$ & 0.9998 & $3.038 \pm 0.028$ \\
24 & $0.734 \pm 0.018$ & 0.9998 & $3.295 \pm 0.055$ \\
48 & $0.734 \pm 0.006$ & 0.9999 & $3.180 \pm 0.018$ \\
72 & $0.696 \pm 0.011$ & 0.9999 & $3.124 \pm 0.017$ \\
96 & $0.734 \pm 0.024$ & 0.9997 & $2.682 \pm 0.047$ \\
\hline
\end{tabular}

Accuracy studies for the determination of $\mathrm{Mg}$ and $\mathrm{Ca}$.

Since the determination of $\mathrm{Mg}$ and $\mathrm{Ca}$ in biodiesel by AAS (proposed in the present study) is in contrast to well established norms, which recommend the use of ICP OES for this determination, a comparative study was performed. Biodiesel samples were analyzed by the proposed AAS procedure and the usual EN 14538 procedure based on ICP OES determination. No significant difference was found between the results obtained by both procedures (Figures 1 and 2) confirming their equivalence (paired $t$ test, $\mathrm{p}>0.05)$. 


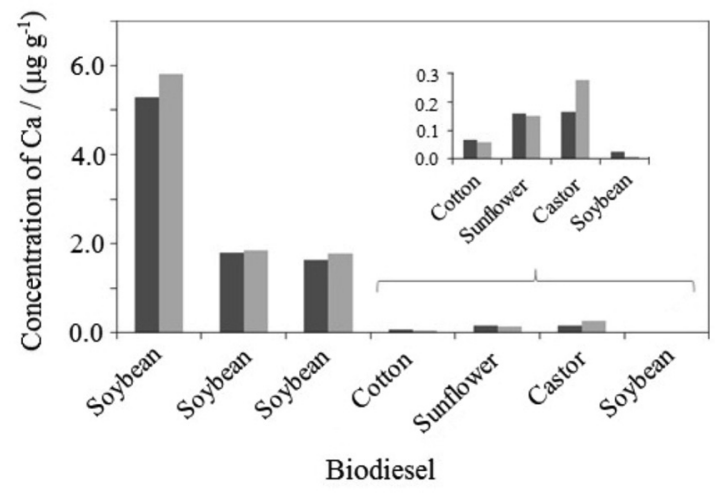

Figure 1. Comparison of the Ca contents in biodiesel samples prepared from different feedstocks found by the proposed NBR ABNT norm AAS procedure ( $\square$ ) and by ICP OES according to the EN 14538 norm (四).

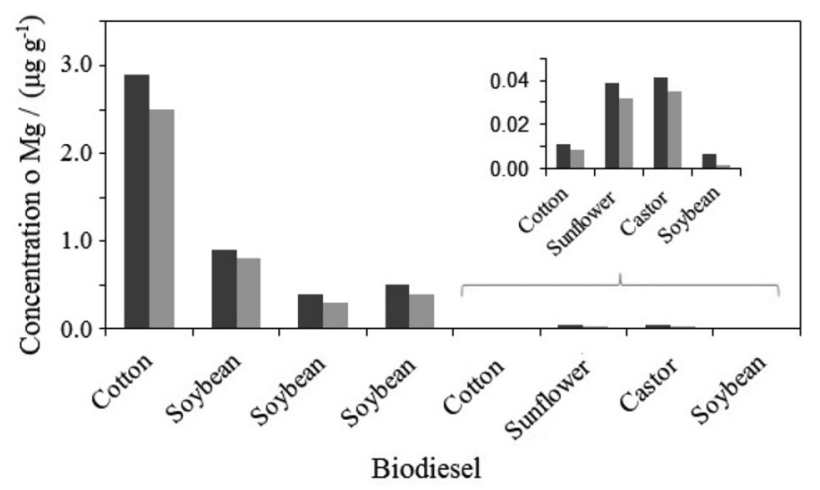

Figure 2. Comparison of the $\mathrm{Mg}$ contents in biodiesel samples prepared from different feedstocks found by the proposed ABNT NBR 15556 norm AAS procedure ( $\mathbf{\square}$ ) and by ICP OES according to the EN 14538 norm ( $\mathbf{\square})$.

\section{Analytical figures of merit and accuracy}

These experiments were performed as described in the Experimental section both by LS F AAS or HR-CS F AAS at the optimized conditions for each instrument. In both instruments, the linearity was observed up to at least $0.4 \mathrm{mg} \mathrm{L}^{-1}$. The instrumental LOD were calculated as three times the standard deviation of 10 measurements of a blank (in the present case a $120.0 \mathrm{~g} \mathrm{~L}^{-1}$ solution of mineral oil in xylene) divided by the slope of the respective calibration curve for each analyte. The LOD was calculated for the original sample, considering the dilution factor. According to Table 4, the LOD obtained using HR-CS FAAS showed improvements for all elements evaluated in comparison with the limits obtained using LS F AAS, although they are all quite below the limits determined by the legislation. Higher sensitivities for $\mathrm{Na}, \mathrm{Mg}$ and $\mathrm{Ca}$ were also observed for the continuous source system probably due to the best fitting of the primary source spectral shape to the absorption line profile promoted by this equipment for these elements (Figure S4). Figure S4 also shows that no spectral interference is observed, and background correction is not mandatory. Regarding to the analysis time, using the HR-CS F AAS spectrometer, the time was 5 times reduced due to the capacity of sequential determination of instrument. However, there is no limitation for performing all these determinations by LS F AAS.

Repeatability and intermediate precision were established by the analysis of calibration solutions with concentrations within the working range. They were determined along 7 successive days, with 5 replicates for each concentration level: $0.15,0.25$ and $0.35 \mathrm{mg} \mathrm{L}^{-1}$. The results obtained for both equipments are displayed in Table 5.

Biodiesel samples of different origins were analyzed as recommended by the NBR ABNT NBR 15556 norm. Determinations were carried out in parallel in both spectrometers (LS F AAS and HR-CS F AAS) by two operators in distinct order to avoid any influence of the stability of the samples or environmental factors. Results in agreement were found (paired $t$ test, $\mathrm{p}>0.05$ ) for all elements in the analysis of the samples by the two instruments. It is important to take into account that the samples and calibration solutions must be prepared just before the analysis in order to avoid stability problems of the diluted solutions already described in the literature ${ }^{15}$ and also observed in the present work as previously discussed. The results obtained are presented in Table 6.

The accuracy was assessed by recovery tests performed with 5 biodiesel samples of different sources. Samples were spiked with 2.0 and $3.0 \mathrm{mg} \mathrm{L}^{-1}$ of $\mathrm{Na}, \mathrm{K}, \mathrm{Mg}$ and $\mathrm{Ca}$, respectively, using the organic standard solution. The results

Table 4. Figures of merit for the determination of $\mathrm{Na}, \mathrm{K}, \mathrm{Mg}$ and $\mathrm{Ca}$ by HR-CS F AAS and LS F AAS using the procedure recommended by the ABNT NBR 15556 norm

\begin{tabular}{|c|c|c|c|c|c|c|}
\hline \multirow{2}{*}{ Analyte } & \multicolumn{3}{|c|}{ HR-CS F AAS } & \multicolumn{3}{|c|}{ LS F AAS } \\
\hline & $\mathrm{c}_{\mathrm{o}} /\left(\mathrm{mg} \mathrm{L}^{-1} 10^{3}\right)$ & $\mathrm{LOD}^{\mathrm{a}} /\left(\mathrm{mg} \mathrm{L}^{-1}\right)$ & $\mathrm{LOD}^{\mathrm{b}} /\left(\mathrm{mg} \mathrm{kg}^{-1}\right)$ & $\mathrm{c}_{\mathrm{o}} /\left(\mathrm{mg} \mathrm{L}^{-1} 10^{3}\right)$ & $\mathrm{LOD}^{\mathrm{a}} /\left(\mathrm{mg} \mathrm{L}^{-1}\right)$ & $\mathrm{LOD}^{\mathrm{b}} /\left(\mathrm{mg} \mathrm{kg}^{-1}\right)$ \\
\hline $\mathrm{Na}$ & 2.7 & 0.009 & 0.10 & 3.5 & 0.020 & 0.23 \\
\hline K & 9.2 & 0.002 & 0.023 & 8.2 & 0.050 & 0.57 \\
\hline $\mathrm{Mg}$ & 1.8 & 0.005 & 0.057 & 2.8 & 0.010 & 0.11 \\
\hline $\mathrm{Ca}$ & 23 & 0.03 & 0.34 & 30 & 0.045 & 0.52 \\
\hline
\end{tabular}

LOD $^{\mathrm{a}}$ : instrumental limit of detection; $\mathrm{LOD}^{\mathrm{b}}$ : limit of detection in the original sample $\left(10.0 \% \mathrm{~m} / \mathrm{v}\right.$ dilution); $\mathrm{c}_{\mathrm{o}}$ : characteristic concentration. 
Table 5. Repeatability and intermediate precision obtained for HR-CS F AAS and LS F AAS at three concentration levels ( $\mathrm{n}=5,7$ days of measurements) using the procedure recommended by the ABNT NBR norm

\begin{tabular}{|c|c|c|c|c|c|c|c|c|}
\hline \multirow{3}{*}{$\begin{array}{l}\text { Concentration / } \\
\left(\mathrm{mg} \mathrm{L}^{-1}\right)\end{array}$} & \multicolumn{4}{|c|}{ Repeatability (CV / \%) } & \multicolumn{4}{|c|}{ Intermediate precision $(\mathrm{CV} / \%)$} \\
\hline & $\mathrm{Na}$ & $\mathrm{K}$ & $\mathrm{Mg}$ & $\mathrm{Ca}$ & $\mathrm{Na}$ & $\mathrm{K}$ & $\mathrm{Mg}$ & $\mathrm{Ca}$ \\
\hline & \multicolumn{8}{|c|}{ HR-CS F AAS } \\
\hline 0.15 & 0.77 & 1.97 & 0.65 & 1.12 & 1.33 & 3.44 & 0.80 & 2.04 \\
\hline 0.25 & 0.67 & 2.08 & 0.58 & 0.77 & 2.94 & 3.57 & 2.04 & 5.10 \\
\hline \multirow[t]{2}{*}{0.35} & 0.71 & 1.60 & 0.78 & 1.40 & 1.69 & 3.13 & 3.52 & 6.36 \\
\hline & \multicolumn{8}{|c|}{ LS F AAS } \\
\hline 0.15 & 0.52 & 1.20 & 0.35 & 3.04 & 1.87 & 1.56 & 0.96 & 3.22 \\
\hline 0.25 & 0.23 & 0.62 & 0.29 & 1.11 & 2.93 & 1.27 & 0.50 & 7.95 \\
\hline 0.35 & 0.37 & 0.83 & 0.20 & 0.92 & 1.60 & 1.63 & 0.53 & 7.92 \\
\hline
\end{tabular}

$\mathrm{CV}$ : coefficient of variation.

obtained are presented in Tables 7 and 8 and recoveries ranged between 91 and $107 \%$.

Accuracy was also assessed by the participation in two proficiency exercises ${ }^{25,26}$ promoted by ANP. Table 9 shows the good agreement between found and consensus

Table 6. Concentrations ( \pm standard deviation, SD) of $\mathrm{Na}, \mathrm{K}, \mathrm{Mg}$ and $\mathrm{Ca}$ obtained by HR-CS F AAS and LS F AAS in biodiesel samples $(\mathrm{n}=3)$ using the procedure recommended by the ABNT NBR 15556 norm

\begin{tabular}{lccccc}
\hline & \multicolumn{3}{c}{ Concentration $\pm \mathrm{SD} /\left(\mathrm{mg} \mathrm{kg}^{-1}\right)$} \\
\cline { 2 - 3 } Analyte & \multicolumn{2}{c}{ HR-CS F AAS } & & \multicolumn{2}{c}{ LS F AAS } \\
\cline { 2 - 3 } \cline { 5 - 6 } & Soybean & Castor & & Soybean & Castor \\
\hline $\mathrm{Na}$ & $0.54 \pm 0.01$ & $0.93 \pm 0.04$ & & $0.59 \pm 0.01$ & $0.98 \pm 0.06$ \\
$\mathrm{~K}$ & $<\mathrm{LOD}$ & $9.20 \pm 0.60$ & & $<\mathrm{LOD}$ & $10.00 \pm$ \\
$\mathrm{Mg}$ & $0.59 \pm 0.08$ & $<\mathrm{LOD}$ & & $0.47 \pm 0.03$ & $<\mathrm{LOD}$ \\
$\mathrm{Ca}$ & $<$ LOD & $2.11 \pm 0.02$ & & $<$ LOD & $2.09 \pm 0.01$ \\
\hline
\end{tabular}

Table 7. Recoveries ( \pm standard deviation, $\mathrm{n}=3$,) in the determination of $\mathrm{Na}, \mathrm{K}, \mathrm{Mg}$ and $\mathrm{Ca}$ in spiked ( 2 and $3 \mathrm{mg} \mathrm{L}^{-1}$ ) biodiesel samples of different sources by HR-CS F AAS using the procedure recommended by the ABNT NBR 15556 norm

\begin{tabular}{lcccc}
\hline & \multicolumn{4}{c}{ Recovery $\pm \mathrm{SD} /\left(\mathrm{mg} \mathrm{L}^{-1}\right)$} \\
\cline { 2 - 5 } Biodiesel & $\mathrm{Na} \mathrm{K}$ & $\mathrm{Mg}$ \\
\cline { 2 - 5 } & \multicolumn{4}{c}{$2 \mathrm{mg} \mathrm{L}^{-1}$} \\
\hline Palm & $2.00 \pm 0.01$ & $1.91 \pm 0.01$ & $2.02 \pm 0.08$ & $1.88 \pm 0.01$ \\
Castor & $1.94 \pm 0.04$ & $1.91 \pm 0.01$ & $2.03 \pm 0.02$ & $1.83 \pm 0.01$ \\
Sunflower & $2.02 \pm 0.02$ & $2.07 \pm 0.01$ & $2.01 \pm 0.03$ & $1.92 \pm 0.01$ \\
Soybean & $1.98 \pm 0.04$ & $1.95 \pm 0.01$ & $2.04 \pm 0.03$ & $1.84 \pm 0.01$ \\
Peanuts & $1.97 \pm 0.01$ & $1.98 \pm 0.01$ & $2.07 \pm 0.01$ & $1.91 \pm 0.01$ \\
\hline & \multicolumn{5}{c}{$3 \mathrm{mg} \mathrm{L}^{-1}$} \\
\hline Palm & $2.98 \pm 0.03$ & $3.05 \pm 0.01$ & $2.99 \pm 0.10$ & $3.00 \pm 0.01$ \\
Castor & $3.00 \pm 0.03$ & $2.84 \pm 0.02$ & $3.12 \pm 0.02$ & $2.86 \pm 0.00$ \\
Sunflower & $2.89 \pm 0.10$ & $2.74 \pm 0.01$ & $2.80 \pm 0.10$ & $3.05 \pm 0.01$ \\
Soybean & $2.97 \pm 0.01$ & $2.98 \pm 0.03$ & $3.21 \pm 0.01$ & $3.15 \pm 0.00$ \\
Peanuts & $2.99 \pm 0.03$ & $3.05 \pm 0.02$ & $3.12 \pm 0.11$ & $3.15 \pm 0.00$ \\
\hline
\end{tabular}

results. Figure S5 shows all the results of the two exercises, highlighting those found in the present work using the ABNT NBR 15556 norm.

In fact, the apparent discrepancy between found and consensus results for $\mathrm{K}$ at the $6^{\text {th }}$ PI may be explained by the fact that this value is close to the limit of

Table 8. Recoveries ( \pm standard deviation, $\mathrm{SD}, \mathrm{n}=3$ ) in the determination of $\mathrm{Na}, \mathrm{K}, \mathrm{Mg}$ and $\mathrm{Ca}$ spiked ( 2 and $3 \mathrm{mg} \mathrm{L}^{-1}$ ) biodiesel samples of different sources by LS F AAS using the procedure recommended by the ABNT NBR 15556 norm

\begin{tabular}{lcccc}
\hline \multirow{2}{*}{ Biodiesel } & \multicolumn{4}{c}{ Recovery $\pm \mathrm{SD} /\left(\mathrm{mg} \mathrm{L}^{-1}\right)$} \\
\cline { 2 - 5 } & $\mathrm{Na}$ & \multicolumn{4}{c}{$\mathrm{Mg}$} & $\mathrm{Ca}$ \\
\cline { 2 - 5 } & \multicolumn{4}{c}{$2 \mathrm{mg} \mathrm{L}^{-1}$} \\
Palm & $1.83 \pm 0.01$ & $1.84 \pm 0.01$ & $1.85 \pm 0.02$ & $1.98 \pm 0.04$ \\
Castor & $1.88 \pm 0.00$ & $1.89 \pm 0.01$ & $1.86 \pm 0.02$ & $2.11 \pm 0.02$ \\
Sunflower & $1.86 \pm 0.01$ & $2.13 \pm 0.00$ & $1.83 \pm 0.02$ & $1.88 \pm 0.03$ \\
Soybean & $1.91 \pm 0.01$ & $2.09 \pm 0.01$ & $1.87 \pm 0.02$ & $1.87 \pm 0.03$ \\
Peanuts & $1.96 \pm 0.01$ & $1.92 \pm 0.00$ & $1.88 \pm 0.03$ & $1.86 \pm 0.04$ \\
\hline & \multicolumn{4}{c}{$3 \mathrm{mg} \mathrm{L}^{-1}$} \\
\hline Palm & $2.75 \pm 0.01$ & $2.73 \pm 0.01$ & $3.16 \pm 0.02$ & $2.78 \pm 0.02$ \\
Castor & $2.79 \pm 0.02$ & $3.12 \pm 0.01$ & $3.12 \pm 0.03$ & $3.10 \pm 0.03$ \\
Sunflower & $2.80 \pm 0.01$ & $3.12 \pm 0.01$ & $2.75 \pm 0.04$ & $3.01 \pm 0.02$ \\
Soybean & $2.86 \pm 0.02$ & $3.01 \pm 0.01$ & $2.76 \pm 0.03$ & $2.81 \pm 0.01$ \\
Peanuts & $2.87 \pm 0.02$ & $2.78 \pm 0.01$ & $2.79 \pm 0.02$ & $2.82 \pm 0.04$ \\
\hline
\end{tabular}

Table 9. Found (ABNT NBR 15556 norm) and consensus values ( \pm standard deviation, SD) in the determination of $\mathrm{Na}$ and $\mathrm{K}$ in biodiesel samples in two ANP proficiency interlaboratory exercises (PI) by LS F AAS

\begin{tabular}{lcccc}
\hline Analyte & $\begin{array}{c}\text { Found / } \\
\left(\mathrm{mg} \mathrm{kg}^{-1}\right)\end{array}$ & $\begin{array}{c}6^{\text {th }} \mathrm{PI} \mathrm{ANP}^{25} / \\
\left(\mathrm{mg} \mathrm{kg}^{-1}\right)\end{array}$ & $\begin{array}{c}\text { Found / } \\
\left(\mathrm{mg} \mathrm{kg}^{-1}\right)\end{array}$ & $\begin{array}{c}7^{\text {th }} \mathrm{PI} \mathrm{ANP}^{26} / \\
\mathrm{M}\left(\mathrm{mg} \mathrm{kg}^{-1}\right)\end{array}$ \\
\hline $\mathrm{Na}$ & $4.44 \pm 0.03$ & $5.05 \pm 1.17$ & $2.89 \pm 0.30$ & $2.59 \pm 0.74$ \\
$\mathrm{~K}$ & $0.13 \pm 0.03$ & $0.66 \pm 0.66$ & $1.91 \pm 0.03$ & $1.93 \pm 0.55$ \\
$\mathrm{Mg}$ & $4.15 \pm 0.07^{\mathrm{a}}$ & $4.87 \pm 0.84$ & & \\
$\mathrm{Ca}$ & $4.44 \pm 0.15^{\mathrm{a}}$ & $4.99 \pm 0.87$ & & \\
\hline
\end{tabular}

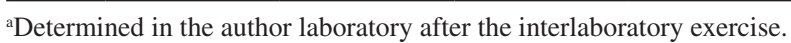


quantification of the method. Moreover, the dispersion of the interlaboratory results is large. If the values out of the $3 \mathrm{~s}$ interval were not considered in the average calculation, they would be too close to the value found in the present work.

\section{Conclusions}

Sodium, $\mathrm{K}, \mathrm{Mg}$ and $\mathrm{Ca}$ can be determined in biodiesel samples obtained from different feedstock by F AAS, with limits of detection adequate for biodiesel characterization according to the current legislation. The amount of $120.0 \mathrm{~g} \mathrm{~L}^{-1}$ mineral oil in xylene solution provided the adequate medium for the preparation of the calibration solutions, allowing the viscosity matching between calibration and sample solutions. In this way, the sensitivity response in biodiesel samples of different sources showed no statistical difference, and external calibration could be performed by the adequate dilution of standard organic solutions in the $120.0 \mathrm{~g} \mathrm{~L}^{-1}$ mineral oil in xylene medium. In comparison to the determination of these metals in aqueous medium, lower aspiration rates should be used, otherwise the flame could become too lean and multiplicative matrix effects could appear. Magnesium and $\mathrm{Ca}$ concentrations found in biodiesel samples of different sources by the developed $\mathrm{F}$ AAS procedure were equivalent to those found by ICP OES following the EN 14538 norm, supporting the ability of $F$ AAS to perform the determination of not only $\mathrm{Na}$ and $\mathrm{K}$, but also of these other two analytes in biodiesel samples of different sources. This information is important since a recent work $^{27}$ has shown that $\mathrm{P}$ can be successfully determined with adequate LOD in biodiesel by GF AAS (graphite furnace atomic absorption spectrometry), and AAS equipment provided with both flame and graphite furnace atomizers can be applied for the regulatory elemental analysis ( $\mathrm{Na}, \mathrm{K}, \mathrm{Mg}, \mathrm{Ca}$ and $\mathrm{P}$ ) imposed to biodiesel. This is also true for ICP OES (NBR 15553 norm), but in fact it is no longer necessary to purchase both equipments for biodiesel characterization, bringing considerable economy to the producers. Thus, from now on, the choice for the type of equipment is up to each laboratory depending on its particular needs and characteristics.

The repeatability and intermediate precision tests have confirmed the adequacy of the proposed procedure and its robustness as well. The use of HR-CS F AAS provided higher sensitivity and better LOD in relation to LS F AAS. However, its main advantage was in relation to the analysis time, which was reduced in 5 times due to the possibility of sequential determination offered by the instrument. Recovery tests as well as the participation in interlaboratory exercises showed that both instruments can be used with good accuracy and precision leading to appropriate LODs for these determinations.

\section{Acknowledgements}

The authors are grateful to Conselho Nacional de Desenvolvimento Científico e Tecnológico (CNPq), Coordenação de Aperfeiçoamento de Pessoal de Nível Superior (CAPES), Pontifícia Universidade Católica do Rio de Janeiro (PUC-Rio), Petrobras and Financiadora de Estudos e Projetos (FINEP).

\section{Supplementary Information}

Supplementary data are available free of charge at http://jbcs.sbq.org.br as PDF file.

\section{References}

1. Knothe, G.; Gerpen, J. V.; Krahl, J.; The Biodiesel Handbook; AOCS Press: Champaign, Illinois, 2005.

2. Bozbas, K.; Renewable Sustainable Energy Rev. 2008, 12, 542.

3. Demirbas, A.; Energy Convers. Manage 2003, 44, 2093.

4. Pinto, A. C.; Guarieiro, L. L. N.; Rezende, M. J. C.; Ribeiro, N. M.; Torres, E. A.; Lopes, W. A.; Pereira, P. A.; De Andrade. J. B.; J. Braz. Chem. Soc. 2005, 16, 1313.

5. Huang, G.; Chen, F.; Wei, D.; Zhang, X.; Chen, G.; Appl. Energy 2010, 87, 38 .

6. Prankl, H.; Körbitz, W.; Mittelbach, M.; Wörgetter, M.; Review on Biodiesel Standardization World-Wide; Prepared for IEA Bioenergy Task 39, Subtask "Biodiesel", Austria, 2004.

7. Agência Nacional do Petróleo, Gás Natural e Biocombustíveis, Resolução ANP No. 7, 19.3.2008-DOU 20.3.2008.

8. EN 14214/2003: Automotive Fuels - Fatty Acid Methyl Esters (FAME) for Diesel Engines - Requirements and Test Methods, Wien.

9. BS EN 14108/2003: Fat and Oil Derivates - Fatty Acid Methyl Esters (FAME) - Determination of Sodium Content by Atomic Absorption Spectrometry, UK.

10. BS EN 14109/2003: Fat and Oil Derivates - Fatty Acid Methyl Esters (FAME) - Determination of Potassium Content by Atomic Absorption Spectrometry, UK.

11. BS EN 14538/2006: Fat and Oil Derivates - Fatty Acid Methyl Esters (FAME) - Determination of $\mathrm{Ca}, \mathrm{K}, \mathrm{Mg}$ and $\mathrm{Na}$ Contents by Optical Emission Spectral Analysis with Inductively Coupled Plasma (ICP OES), UK.

12. ASTM D6751/10: Standard Specification for Biodiesel Fuel Blend Stock (B100) for Middle Distillate Fuels, USA.

13. Santos, E. J.; Hermann, A. B.; Chaves, E. S.; Vechiatto, W. W. D.; Schoemberger, A. C.; Frescura, V. L. A.; Curtius, A. J.; J. Anal. At. Spectrom. 2007, 22, 1300. 
14. Chaves, E. S.; Saint'Pierre, T. F.; Dos Santos, E. J.; Tormen, L.; Frescura, V. L. A.; Curtius, A. J.; J. Braz. Chem. Soc. 2008, $19,856$.

15. Jesus, A.; Silva, M. M.; Vale, M. G. R.; Talanta 2008, 74, 1378.

16. De Oliveira, A. P.; Villa, R. D.; Antunes, K. C. P.; De Magalhães, A.; Silva, E. C.; Fuel 2009, 88, 764.

17. ABNT NBR 15554/2008: Produtos Derivados de Óleos e Gorduras - Ésteres Metílicos/Etílicos de Ácidos Graxos - Determinação do Teor de Sódio por Espectrometria de Absorção Atômica, Brasil.

18. ABNT NBR 15555/2008: Produtos Derivados de Óleos e Gorduras - Ésteres Metílicos/Etílicos de Ácidos Graxos Determinação do Teor de Potássio por Espectrometria de Absorção Atômica, Brasil.

19. ABNT NBR 15553/2008: Produtos Derivados de Óleos e Gorduras - Ésteres Metílicos/Etílicos de Ácidos Graxos Determinação dos Teores de Cálcio, Magnésio, Sódio, Fósforo e Potássio por Espectrometria de Emissão Ótica com Plasma Indutivamente Acoplado (ICP OES), Brasil.

20. ABNT NBR 15556/2008: Produtos Derivados de Óleos e Gorduras - Ésteres Metílicos/Etílicos de Ácidos Graxos Determinação do Teor De Sódio, Potássio, Magnésio e Cálcio por Espectrometria de Absorção Atômica, Brasil.
21. Welz, B.; Becker-Ross, H.; Florek, S.; Heitmann, U.; Vale, M. G. R.; J. Braz. Chem. Soc. 2003, 14, 220.

22. Quadros, D. P. C.; Rau, M.; Idrees, M.; Chaves, E. S.; Curtius, A. J.; Borges, D. L. G.; Spectrochim. Acta, Part B 2011, 66, 373.

23. Reyes, M. N. M.; Campos, R. C.; Spectrochim. Acta, Part B 2005, 60, 615 .

24. Geris, R.; Dos Santos, N. A. C.; Amaral, B. A.; Maia, I. S.; Castro, V. D.; Carvalho, J. R. M.; Quim. Nova 2007, 30, 1369.

25. $6^{\text {th }}$ ANP interlaboratory exercises (PI). Final report, Programa de Comparação Interlaboratorial em Biodiesel da ANP, ANP, Brasil.

26. $7^{\text {th }}$ ANP interlaboratory exercises (PI). Final report, Programa de Comparação Interlaboratorial em Biodiesel da ANP, ANP, Brasil.

27. Campos, R. C.; Correia, C. L. T.; Vieira, F.; Saint' Pierre, T. D.; Oliveira, A. C.; Gonçalves, R. A.; Spectrochim. Acta, Part B 2011, 66, 352.

Submitted: March 21, 2012

Published online: June 26, 2012 


\section{Determination of Na, K, Mg and Ca in Biodiesel by LS F AAS and HR-CS F AAS: Studies that Supported the Proposal of the ABNT NBR 15556 Norm}

Ligia C. C. de Oliveira, ${ }^{a}$ Mariana A. Vieira,${ }^{*, b}$ Anderson S. Ribeiro, ${ }^{b}$ Paula M. Baptista, ${ }^{a}$ Rodrigo A. Gonçalves ${ }^{a}$ and Reinaldo C. de Campos ${ }^{\sharp, a}$

${ }^{a}$ Departamento de Química, Pontifícia Universidade Católica do Rio de Janeiro (PUC-Rio),

Rio de Janeiro-RJ, Brazil

${ }^{b}$ Laboratório de Metrologia Química, Centro de Ciências Químicas, Farmacêuticas e de Alimentos, Programa de Pós-Graduação em Química, Universidade Federal de Pelotas (UFPel),

96160-000 Capão do Leão-RS, Brazil

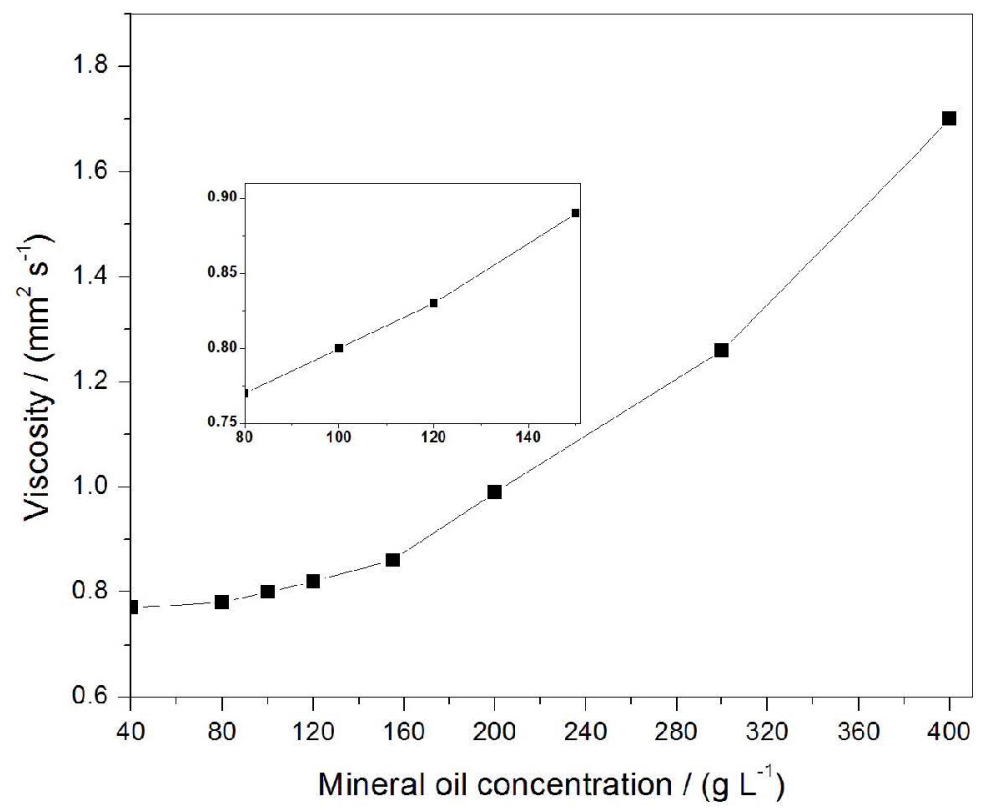

Figure S1. Viscosity of mineral oil in xylene solutions as function of the mineral oil concentration.

*e-mail: maryanavieira@hotmail.com

\#In memoriam

Dedicatory: This work is dedicated to Professor Reinaldo Calixto de Campos who passed away on February 7th, 2012. The same day Reinaldo and some authors discussed the last details to finish this work. We would like to thank Reinaldo for his contribution to the development of the Analytical Chemistry in Brazil. 
$\mathrm{Na}$

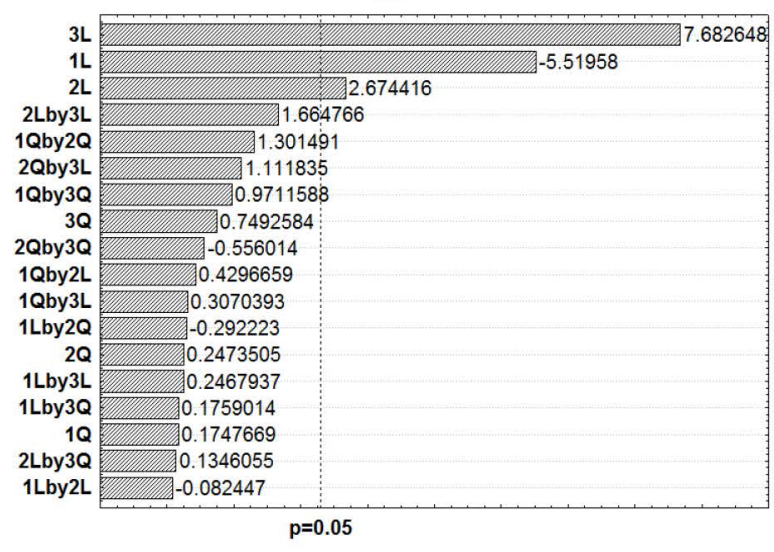

Mg

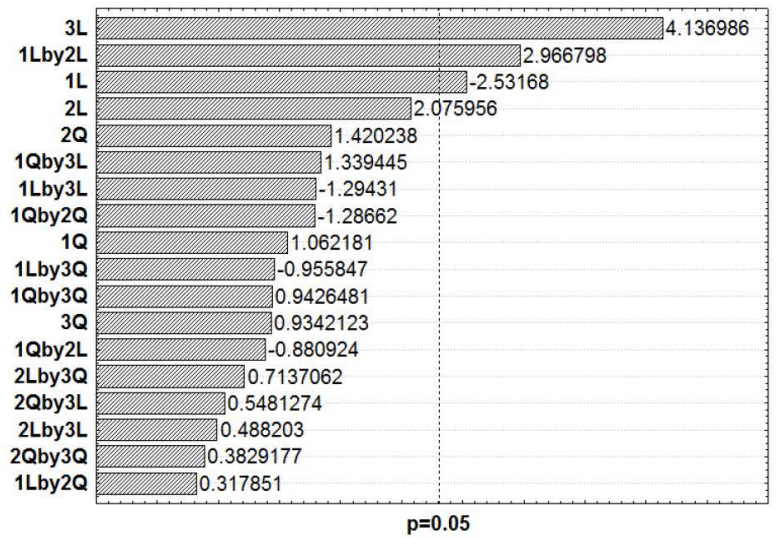

K

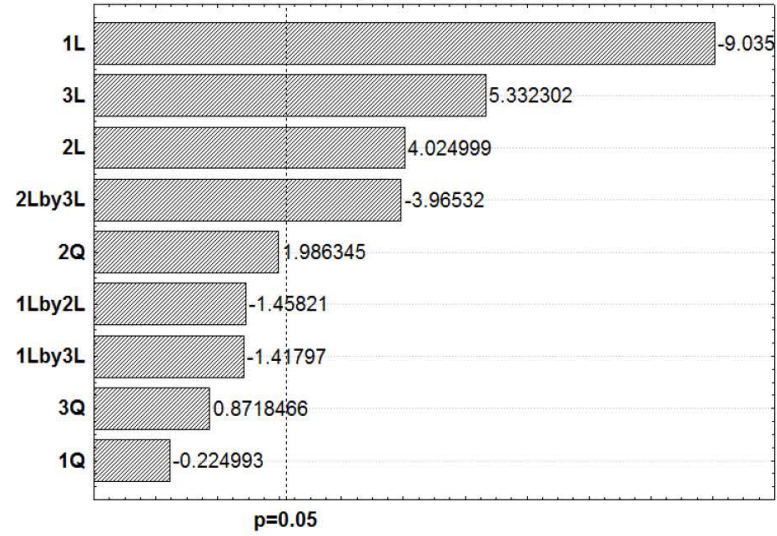

Ca

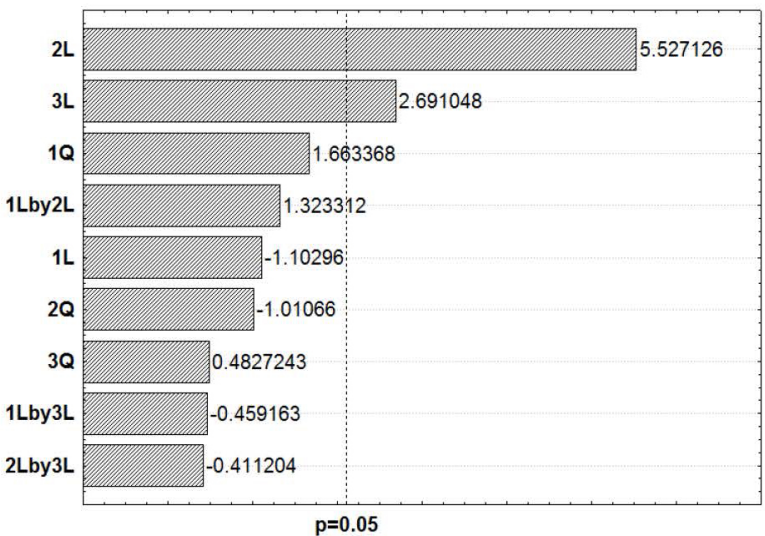

Figure S2. Pareto charts relatively to the factorial planning of the determination of $\mathrm{Na}, \mathrm{K}, \mathrm{Mg}$ and Ca in biodiesel by FAAS, (1) burner height, (2) acetylene flow rate and (3) aspiration rate. 

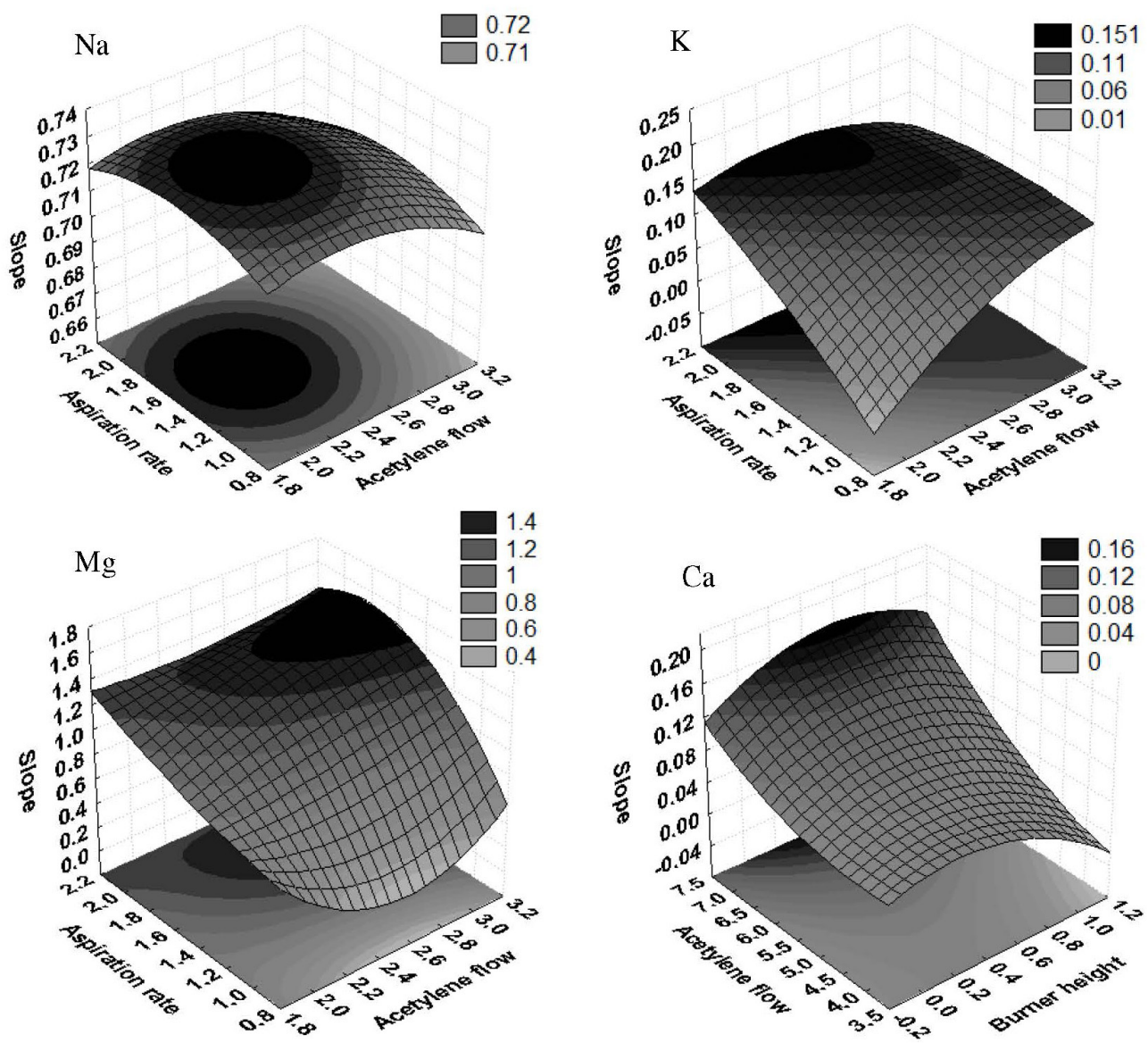

Figure S3. Response surfaces of the optimization experiment in the determination of $\mathrm{Na}, \mathrm{K}, \mathrm{Mg}$ and $\mathrm{Ca}$ in biodiesel by F AAS, slope ( $\left.\mathrm{L} \mathrm{mg}^{-1}\right)$, acetylene flow rate $\left(\mathrm{L} \mathrm{min}^{-1}\right)$, burner height $(\mathrm{cm})$ and aspiration rate $\left(\mathrm{mL} \mathrm{min}^{-1}\right)$.
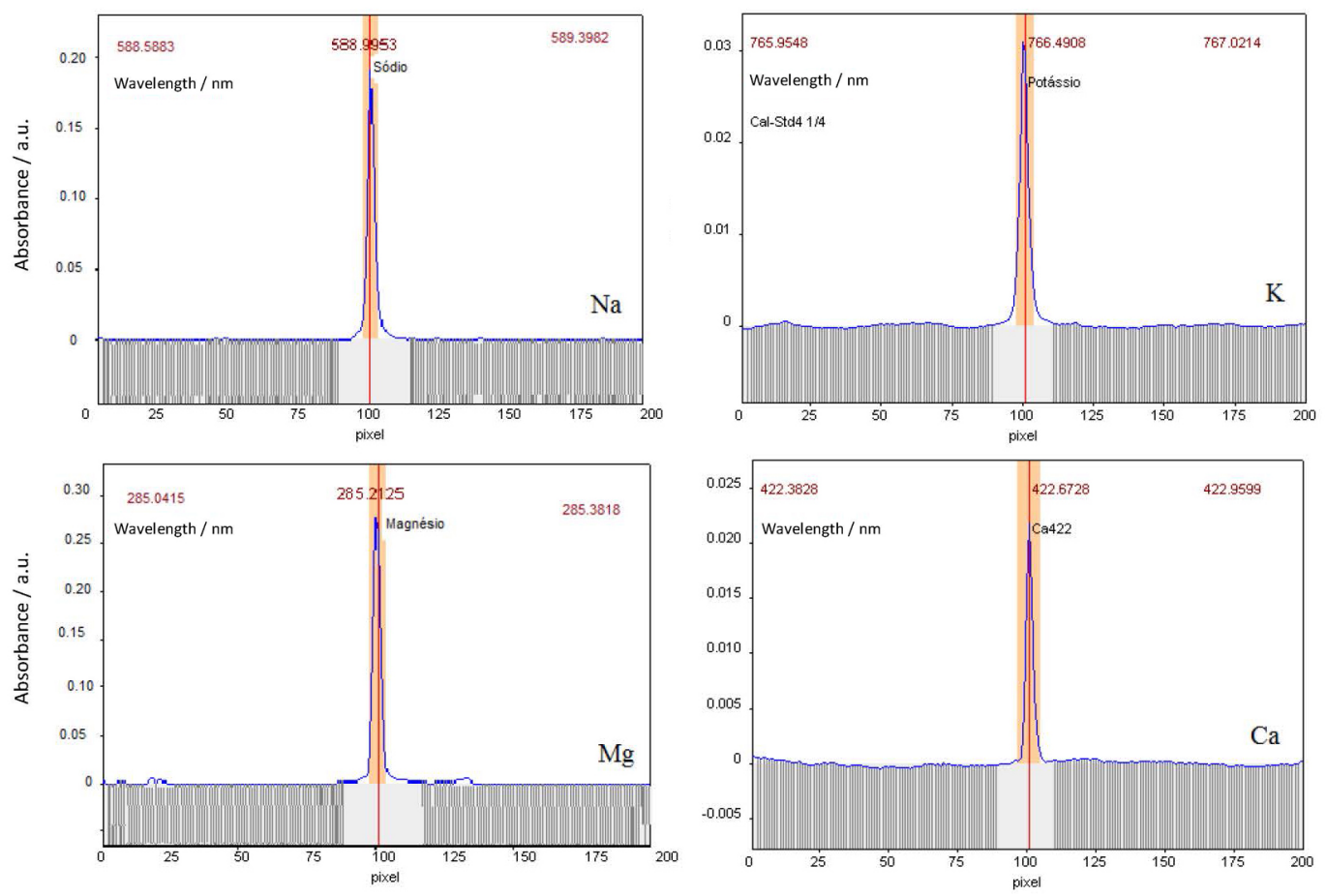

Figure S4. Spectral absorption profiles of $\mathrm{Na}, \mathrm{K}, \mathrm{Mg}$ and $\mathrm{Ca}$ in a biodiesel sample by HR-CS F AAS. 

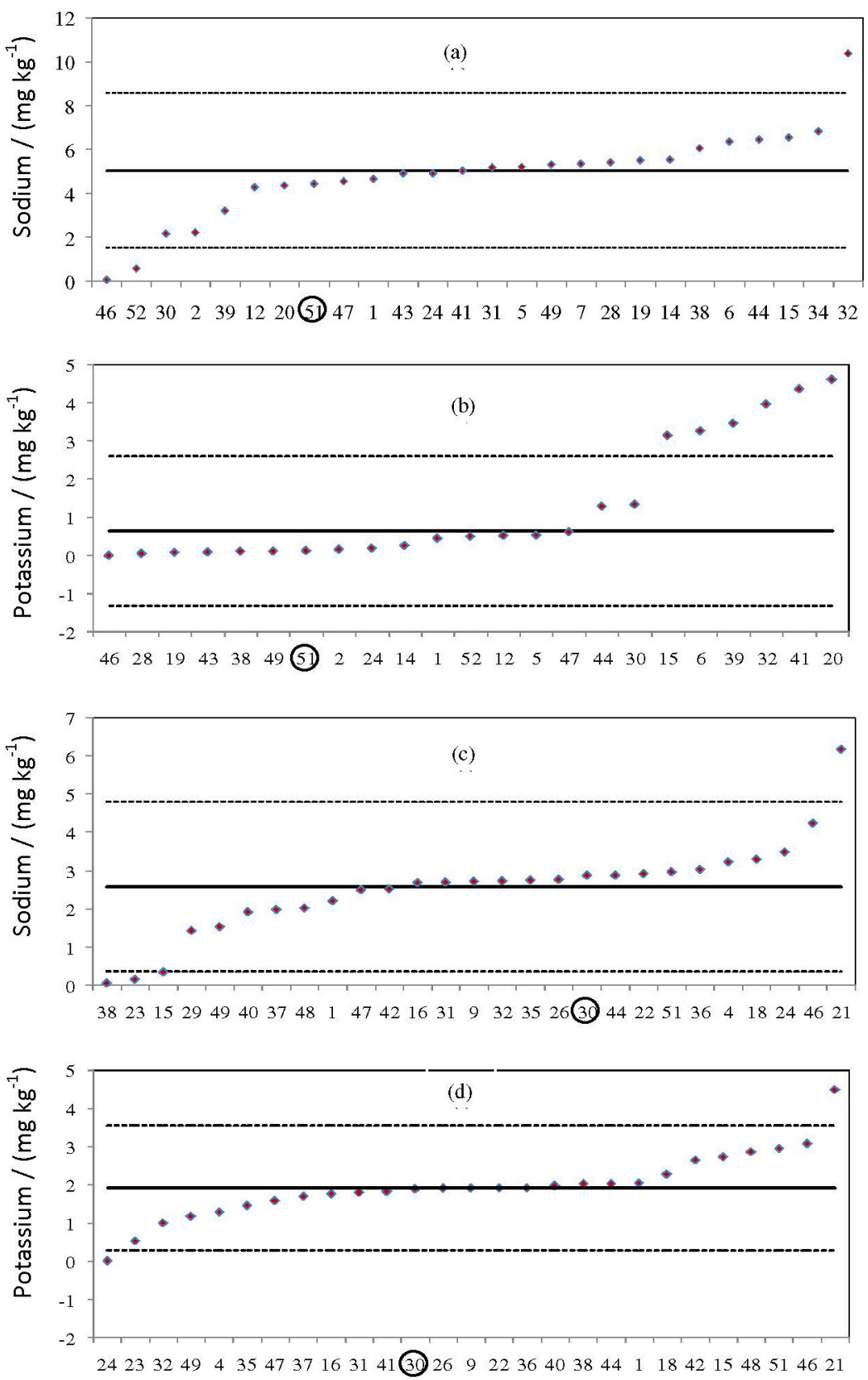

Figure S5. Graphical representation of the results of the $6^{\text {th }}$ and $7^{\text {th }}$ ANP interlaboratory exercises (PI), highlighting the results found in the present work using the ABNT NBR 15556 norm (51 and 30) in relation to the other participants: (a) Na $6^{\text {th }}$ PI, (b) K $6^{\text {th }}$ PI, (c) Na $7^{\text {th }}$ PI and (d) K $7^{\text {th }}$ PI, ( $\bullet$ ) results, (一) average and (---) $\pm 3 \mathrm{~s}$. 
Table S1. Instrumental parameters for the determination of $\mathrm{Na}, \mathrm{K}, \mathrm{Mg}$ and $\mathrm{Ca}$ by LS F AAS and HR-CS F AAS

\begin{tabular}{|c|c|c|c|c|c|c|c|c|}
\hline \multirow{2}{*}{ Parameters } & \multicolumn{4}{|c|}{ LS F AAS } & \multicolumn{4}{|c|}{ HR-CS F AAS } \\
\hline & $\mathrm{Na}$ & $\mathrm{K}$ & $\mathrm{Mg}$ & $\mathrm{Ca}$ & $\mathrm{Na}$ & $\mathrm{K}$ & $\mathrm{Mg}$ & $\mathrm{Ca}$ \\
\hline Lamp current / mA & 10 & 10 & 4 & 4 & \multicolumn{4}{|c|}{ hot spot mode } \\
\hline$\lambda / \mathrm{nm}$ & 589 & 766.5 & 285.2 & 422.5 & 588.99 & 766.49 & 285.21 & 422.67 \\
\hline Spectral resolution / nm - Number of pixels & 0.8 & 0.8 & 1.2 & 1.2 & 7 & 7 & 7 & 9 \\
\hline Integration time / s & 3.5 & 3.5 & 3.5 & 3.5 & 3.0 & 3.0 & 3.0 & 3.0 \\
\hline Aspiration rate $\left./(\mathrm{mL} \mathrm{min})^{-1}\right)$ & 1.5 & 1.5 & 1.5 & 1.5 & 1.6 & 1.6 & 1.6 & 1.6 \\
\hline $\mathrm{C}_{2} \mathrm{H}_{2}$ flow rate $/\left(\mathrm{L} \mathrm{min}^{-1}\right)$ & 2.2 & 2.2 & 2.2 & 6.5 & 0.7 & 0.7 & 0.7 & 4.3 \\
\hline $\mathrm{N}_{2} \mathrm{O}$ flow rate $/\left(\mathrm{L} \mathrm{min}^{-1}\right)$ & - & - & - & 7.0 & - & - & - & 10.2 \\
\hline Air flow rate / $\left(\mathrm{L} \mathrm{min}^{-1}\right)$ & 11.5 & 11.5 & 11.5 & - & 12.8 & 12.8 & 12.8 & - \\
\hline Observation height $/ \mathrm{cm}$ & 0.5 & 0.4 & 0.6 & 0.6 & 0.5 & 0.4 & 0.6 & 0.4 \\
\hline
\end{tabular}

Table S2. Factors and their respective levels in the $3^{3}$ factorial planning

\begin{tabular}{|c|c|c|c|c|c|c|}
\hline \multirow{3}{*}{ Factors } & \multicolumn{6}{|c|}{ Levels } \\
\hline & \multicolumn{3}{|c|}{$\mathrm{Na}, \mathrm{K}, \mathrm{Mg}$} & \multicolumn{3}{|c|}{$\mathrm{Ca}$} \\
\hline & -1 & 0 & +1 & -1 & 0 & +1 \\
\hline 1- Burner height / cm & 0 & 0.5 & 1 & 0 & 0.5 & 1 \\
\hline 2- $\mathrm{C}_{2} \mathrm{H}_{2}$ flow rate / $\left(\mathrm{L} \mathrm{min}^{-1}\right)$ & 2 & 2.5 & 3 & 4 & 5.5 & 7 \\
\hline 3- Aspiration rate / $\left(\mathrm{mL} \mathrm{min}^{-1}\right)$ & 1 & 1.5 & 2 & 1 & 1.5 & 2 \\
\hline
\end{tabular}

Table S3. Response obtained from $3^{3}$ factorial planning for $\mathrm{Na}, \mathrm{K}$ and $\mathrm{Mg}$

\begin{tabular}{|c|c|c|c|c|c|c|}
\hline \multirow{2}{*}{ Experiment } & \multirow{2}{*}{ Burner height $/ \mathrm{cm}$} & \multirow{2}{*}{ Acetylene flow / $\left(\mathrm{L} \mathrm{min}^{-1}\right)$} & \multirow{2}{*}{ Aspiration rate $/\left(\mathrm{mL} \min ^{-1}\right)$} & \multicolumn{3}{|c|}{ Slope / $\left(\mathrm{L} \mathrm{mg}^{-1}\right)$} \\
\hline & & & & $\mathrm{Na}$ & $\mathrm{K}$ & $\mathrm{Mg}$ \\
\hline 1 & 0 & 2 & 1 & 0.684 & 0.056 & 0.672 \\
\hline 2 & 0 & 2 & 1.5 & 0.697 & 0.067 & 1.256 \\
\hline 3 & 0 & 2 & 2 & 0.699 & 0.186 & 1.545 \\
\hline 4 & 0 & 2.5 & 1 & 0.708 & 0.113 & 1.078 \\
\hline 5 & 0 & 2.5 & 1.5 & 0.717 & 0.204 & 1.332 \\
\hline 6 & 0 & 2.5 & 2 & 0.712 & 0.193 & 1.499 \\
\hline 7 & 0 & 3 & 1 & 0.713 & 0.163 & 0.748 \\
\hline 8 & 0 & 3 & 1.5 & 0.723 & 0.171 & 1.217 \\
\hline 9 & 0 & 3 & 2 & 0.719 & 0.156 & 1.172 \\
\hline 10 & 0.5 & 2 & 1 & 0.725 & 0.020 & 0.634 \\
\hline 11 & 0.5 & 2 & 1.5 & 0.726 & 0.098 & 1.258 \\
\hline 12 & 0.5 & 2 & 2 & 0.721 & 0.128 & 1.382 \\
\hline 13 & 0.5 & 2.5 & 1 & 0.711 & 0.071 & 0.576 \\
\hline 14 & 0.5 & 2.5 & 2 & 0.723 & 0.110 & 1.424 \\
\hline 15 & 0.5 & 3 & 1 & 0.711 & 0.105 & 0.852 \\
\hline 16 & 0.5 & 3 & 1.5 & 0.714 & 0.112 & 1.295 \\
\hline 17 & 0.5 & 3 & 2 & 0.729 & 0.126 & 1.425 \\
\hline 18 & 0.5 & 2 & 1 & 0.726 & 0.010 & 0.790 \\
\hline 19 & 1 & 2 & 1.5 & 0.734 & 0.033 & 0.083 \\
\hline 20 & 1 & 2 & 2 & 0.727 & 0.079 & 0.302 \\
\hline 21 & 1 & 2.5 & 1 & 0.704 & 0.046 & 0.766 \\
\hline 22 & 1 & 2.5 & 1.5 & 0.715 & 0.075 & 1.131 \\
\hline 23 & 1 & 2.5 & 2 & 0.711 & 0.071 & 1.264 \\
\hline 24 & 1 & 3 & 1 & 0.704 & 0.063 & 0.846 \\
\hline 25 & 1 & 3 & 1.5 & 0.671 & 0.065 & 1.194 \\
\hline 26 & 1 & 3 & 2 & 0.659 & 0.070 & 1.413 \\
\hline 27 & 1 & 2.5 & 1.5 & 0.737 & 0.124 & 1.300 \\
\hline
\end{tabular}


Table S4. Response obtained from $3^{3}$ factorial planning for $\mathrm{Ca}$

\begin{tabular}{|c|c|c|c|c|}
\hline \multirow{2}{*}{ Experiment } & \multirow{2}{*}{ Burner height $/ \mathrm{cm}$} & \multirow{2}{*}{ Acetylene flow / $\left(\mathrm{L} \mathrm{min}^{-1}\right)$} & \multirow{2}{*}{ Aspiration rate $/\left(\mathrm{mL} \mathrm{min}{ }^{-1}\right)$} & \multirow{2}{*}{$\begin{array}{c}\text { Slope / }\left(\mathrm{L} \mathrm{mg}^{-1}\right) \\
\mathrm{Ca}\end{array}$} \\
\hline & & & & \\
\hline 1 & 0 & 4 & 1 & 0.018 \\
\hline 2 & 0 & 4 & 1.5 & 0.043 \\
\hline 3 & 0 & 4 & 2 & 0.077 \\
\hline 4 & 0 & 5.5 & 1 & 0.035 \\
\hline 5 & 0 & 5.5 & 1.5 & 0.098 \\
\hline 6 & 0 & 5.5 & 2 & 0.140 \\
\hline 7 & 0 & 7 & 1 & 0.064 \\
\hline 8 & 0 & 7 & 1.5 & 0.126 \\
\hline 9 & 0 & 7 & 2 & 0.109 \\
\hline 10 & 0.5 & 4 & 1 & 0.059 \\
\hline 11 & 0.5 & 4 & 1.5 & 0.050 \\
\hline 12 & 0.5 & 4 & 2 & 0.058 \\
\hline 13 & 0.5 & 5.5 & 1 & 0.035 \\
\hline 14 & 0.5 & 5.5 & 2 & 0.109 \\
\hline 15 & 0.5 & 7 & 1 & 0.192 \\
\hline 16 & 0.5 & 7 & 1.5 & 0.142 \\
\hline 17 & 0.5 & 7 & 2 & 0.123 \\
\hline 18 & 1 & 4 & 1 & $-{ }^{\mathrm{a}}$ \\
\hline 19 & 1 & 4 & 1.5 & $-^{\mathrm{a}}$ \\
\hline 20 & 1 & 4 & 2 & 0.055 \\
\hline 21 & 1 & 5.5 & 1 & 0.034 \\
\hline 22 & 1 & 5.5 & 1.5 & 0.059 \\
\hline 23 & 1 & 5.5 & 2 & 0.045 \\
\hline 24 & 1 & 7 & 1 & 0.060 \\
\hline 25 & 1 & 7 & 1.5 & 0.156 \\
\hline 26 & 1 & 7 & 2 & 0.150 \\
\hline 27 & 0.5 & 5.5 & 1.5 & 0.065 \\
\hline
\end{tabular}

${ }^{\text {aNo response. }}$ 